\title{
CONTEXTUAL TEACHING AND LEARNING BASED ON LEARNING MODULE FOR SDN 09 AIRPURA SELATAN COASTAL
}

\author{
Hidayati Azkiya ${ }^{1}$, Syofiani ${ }^{2}$, Romi Isnanda ${ }^{3}$, and Devika Sri Yunda ${ }^{4}$ \\ \{hidayatiazkiya@bunghatta.ac.id ${ }^{1}$, syofiani.jufri@gmail.com ${ }^{2}$ \} \\ ${ }^{1,2,3}$ Major of Elementary School Teacher Education Faculty of Teacher Training and Education Bung \\ Hatta University, Indonesia
}

\begin{abstract}
This study aims to develop an Indonesian Language Learning Module with a Contextual Teaching and Learning Approach on child rhyming material for Grade IV students of SD Negeri 09 Airpura Pesisir Selatan. The theory used as a reference is the opinion of Hasan [1] about learning, Bowers opinion [2] about the module and Kurniati [3] opinion about the Contextual Teaching and Learning approach.. This research was conducted in fourth grade students even semester 2018/2019 Academic Year. Data collection was carried out with validation and trial modules developed. The module design that was designed was validated by two experts then tested in class IV A SDN 09 Airpura to find out practicality. The results showed that the Indonesian language learning module with the Contextual Teaching and Learning Approach on child rhyming material for fourth grade students at SD 09 Airpura was in a very practical category with an average percentage of practicality 91.31 by students. The results of the validation by two experts obtained a value of 96.87 which is included in the category of very valid and the practicality score of the teacher of 100 which is included in the category of very practical.
\end{abstract}

Keywords: module, contextual teaching and learning approach

\section{Introduction}

The learning process is basically a process of learning and teaching that cannot be separated from one another. Teaching and learning process is a process of interaction between two human elements, namely students as the learning party and the teacher as the teaching party, with students as the main subject. Through Indonesian subjects in primary schools, students are expected to have knowledge and insights about the basic Indonesian language. In order to achieve the objectives of Indonesian language must be supported by a conducive learning process because learning developed by the teacher has a very big influence on learning success. Likewise learning success is greatly influenced by the ability and accuracy 
of teachers in choosing and using various approaches and strategies in learning. One of the abilities that must be possessed by teachers in carrying out the Indonesian learning process is to use appropriate and correct media in the teaching and learning process. According to Hanafy [4], learning and learning is a complex process by bringing together components that have their own characteristics that are integrated, interrelated and influence to achieve the expected goals or competencies. Learning components are meant, including objectives, materials, methods, media, and sources, evaluations, students, teachers, and the environment. While Firmansyah [5] revealed that learning is a process or activity that changes the behavior of an individual in gaining knowledge after he gets a learning or experience, this is certainly a change towards a better (positive), for example who had no idea after experience the learning process of at least being know. According to the writing, Md. Kamrul Hasan \& Mohd. Monirzzaman Akhand [7] said that writing is a fluid process created by writers as they work. And in additional Reza Biria \& Sahar Jafari [8] said writing is a complicated process trough which ideas are created and expressed. Indubitably, learning to write is even harder and it takes a considerable amount of time and effort to write skillfully.

Based on observations made in Indonesian language learning conducted on Tuesday 30 October 2018 until Thursday 1 November 2018 in class IV SD Negeri 09 Airpura, Pesisir Selatan Regency, it was found that there were problems in the learning process. Problems found in the Indonesian learning process, including teachers tend to use conventional methods (lectures and questions and answers). In addition, teaching materials used are in the form of Student Work Sheets (LKS) and printed books. Researchers also saw a lack of students' desire to ask questions, even though they had not mastered the material taught by the teacher. This can be seen when the teacher gives questions, only three or four students are able to answer the teacher's questions. To overcome these problems, teaching materials in the form of modules can be developed using one approach to be able to improve student understanding. Kurniati [3] Module is a unified whole, consisting of a series of learning activities, which have clearly provided effective learning outcomes in achieving clearly and specific goals that have been formulated. As for Gusmania [8] explained that the Module is one of the smallest teaching and learning program units which module elements consist of teacher guidelines, student activity sheets, work sheets, answer sheet keys, test sheets, test sheet keys. In addition, Suriyanti \& Yaacop [9] state that descriptive, narrative, expository and argumentative writing are the four most common types of writing. Based on the explanation, the module is one of the learning alternatives that can arouse students' enthusiasm and fun and increase curiosity. One of them is in learning Indonesian by using the Contextual Teaching and Learning approach. According to Enoh [10] Contextual Teaching and Learning (CTL) is a conception that helps teachers link subject content with real-world situations and motivate students to make connections between knowledge and its application in their lives as family members, citizens, and labor. Meanwhile, according to [11], Contextual Teaching and Learning (CTL) is an integrated learning process planning process that uses themes to link certain subjects that are carried out with contextual concepts, namely linking material taught with real-world situations of students so as to improve performance learners. So, through this research, an attempt to develop an Indonesian language learning module by using an educational unit level curriculum (KTSP) based on Contextual Teaching and Learning because there have not been many studies related to the development of modules in learning Indonesian in elementary schools.

Based on the aforementioned description, an alternative is determined, namely developing a module using a Contextual Teaching and Learning-based approach in Indonesian Language Learning Class IV Elementary School 09 Airpura. 


\section{Development Style}

This research is a research and development study with a 4-D development model that is limited to 3-D. This model consists of 4 stages of development, namely: the stage of definition (define), the stage of design (design), the stage of development (develop), and the stage of dissemination (desseminate). In this study, researchers will only go through the development stage (develop) because of the limitation of ability, time and cost.

\section{a. Defining Phase}

According to Trianto [12] the purpose of this stage is to define and define learning conditions. This stage includes namely (a) curriculum analysis; (b) needs analysis; (c) student analysis; and (d) concept analysis.

\section{b. Design Stage}

The results obtained after analyzing the needs, are used to design Indonesian learning modules based on Contextual Teaching and Learning, consisting of several components namely cover / cover, preface, table of contents, material chart, SK, KD, indicators and learning objectives, learning activities and practice questions.

\section{c. Development Phase (Develop)}

According to Trianto [12] the purpose of this stage is to produce a revised learning tool based on expert input. The steps taken are the validation and practicality stages. For the validation stage carried out by experts, the practicality phase is carried out by the teacher and students.

\section{d. Data Analysis Technique}

Module Validation Results Analysis

The results of the validation of the validator for all aspects assessed are presented in tabular form. To find out the module validity, the maximum score is determined first on the validation sheet. follows:

Determine the value of validity by using a formula that was modified from [11] as

Validity value $=($ number of scores obtained $) /($ maximum score $) \times 100 \%$

Table 6. Validity Assessment

\begin{tabular}{|l|l|}
\hline Presentase & Criteria \\
\hline $90 \%-100 \%$ & Very valid \\
\hline $80 \%-89 \%$ & Valid \\
\hline $65 \%-79 \%$ & Valid enaught \\
\hline $55 \%-64 \%$ & Less valid \\
\hline $0 \%-54 \%$ & Invalid \\
\hline
\end{tabular}

Source: Purwanto (Saputri:2015:8) 


\section{e. Analysis of module practicality results}

Data obtained by calculating the score of students who answered each item as contained in the questionnaire. Media practicality test data were analyzed by percentage (\%) using a modified formula from [11] as follows:

Practicality score $=($ total score obtained $) /($ maximum score $) \times 100 \%$

Table 7. Percentage of Practicality Assessment

\begin{tabular}{|l|l|}
\hline Percentage & Criteria \\
\hline $86 \%-100 \%$ & Very practical \\
\hline $76 \%-85 \%$ & practical \\
\hline $60 \%-75 \%$ & Practical enought \\
\hline $55 \%-59 \%$ & Less practical \\
\hline$\leq 54 \%$ & Inpractical \\
\hline
\end{tabular}

Source: Modified from Purwanto [11]

\section{Research Results and Discussion}

\subsection{Data Description}

Before conducting research in elementary school, researchers conducted observations at SDN 09 AirpuraPesisir Selatan in class IV on October 30, 2018 to November 1, 2019 to find out the problem and collect data. After knowing the problem and collecting data, the researcher designed a module with a Contextual Teaching and Learning approach that can help teachers and students in the learning process. After the module has been prepared, the material validity and media validity tests are carried out to determine the weaknesses of the modules so they can be revised immediately.

Experts who tested the material aspects namely Mr. RomiIsnanda, S.Pd.,M.Pd. He is a lecturer in Indonesian Language and Literature Education Study Program. Experts who tested aspects of the media were Mr. AshabulKhairi, ST.M.Kom. He is a lecturer in the Education and Information Technology Study Program. After validation and revision, the module is ready to be tested on a large scale. A large-scale module trial was conducted at SDN 09 Airpura on Tuesday 12 February 2019. The teacher who assessed the practicality of the module was Mrs. ZainatulAnida, S.Pd as the fourth grade A.

\subsection{Result of research}

In general, the results of module validation based on Contextual Teaching and Learning can be illustrated in table 9 as follows:

Table 9. Data Validation Module Results by Validator

\begin{tabular}{|l|l|l|l|l|l|l|}
\hline \multirow{2}{*}{ No } & \multirow{2}{*}{ Aspect of rating } & \multicolumn{2}{|c|}{ Validator Score } & Total & Value of Validity & Criteria \\
\cline { 3 - 7 } & & $\mathbf{1}$ & $\mathbf{2}$ & & & \\
\hline 1 & Content Feasibility & 36 & 36 & 72 & $100 \%$ & Very valid \\
\hline 2 & Language & 20 & 20 & 40 & $100 \%$ & Very valid \\
\hline
\end{tabular}




\begin{tabular}{|l|l|l|l|l|l|l|}
\hline 3 & Presentation & 60 & 60 & 120 & $100 \%$ & Very valid \\
\hline 4 & Grafting & 20 & 22 & 42 & $87,5 \%$ & Valid \\
\hline \multicolumn{7}{|l|}{ Average }
\end{tabular}

Based on Table 9 it can be seen that the percentage of module validations that are considered validator in general is $100 \%$ with a very valid category. From the assessed aspects, the average percentage of content eligibility is $100 \%$, the language and readability aspects are $100 \%$, the presentation aspect is $100 \%$, and the graphic aspect is $87.5 \%$. Table 9 shows that the Indonesian learning module with the Contextual Teaching and Learning approach developed is valid. Following are the results of the validation of the Indonesian learning module with the Contextual Teaching and Learning approach in brief by expert lecturers. Through the results of practicality by the fourth grade elementary school teacher 09 Airpura, the recapitulation results obtained from the practicality sheet are seen in table 10 as follows:

Table 10. Results of the Practicality Test of Indonesian Language Learning Modules with the Contextual Teaching and Learning Approach by the Teacher

\begin{tabular}{|l|l|l|l|l|}
\hline No & Rating Aspect & $\begin{array}{l}\text { Total } \\
\text { Score }\end{array}$ & $\begin{array}{l}\text { Persentage of } \\
\text { Practicality }\end{array}$ & Criteria \\
\hline 1 & Ease of use & 20 & $100 \%$ & Very practical \\
\hline 2 & Ractical learning time & 8 & $100 \%$ & Very practical \\
\hline 3 & Benefits & 20 & $100 \%$ & Very practical \\
\hline Average & & 100 & Very practical \\
\hline
\end{tabular}

Based on table 10 it can be explained the percentage of practicality Indonesian Language Learning Module with the Contextual Teaching and Learning Approach to the material rhymes of children by the teacher is 100 with very practical criteria. This shows that This module is very practical to be used by teachers as teaching material on child rhymes.

Table 11. Practicality Test Results of Indonesian Language Learning Modules with the Contextual Teaching and Learning Approach by Students

\begin{tabular}{|l|l|l|l|l|}
\hline $\begin{array}{l}\mathrm{N} \\
\mathrm{o}\end{array}$ & Practicality Variable & Total Score & Ractical Value & Criteria \\
\hline 1 & Student Interest & 590 & $92,18 \%$ & Very Practical \\
\hline 2 & Process of Using & 284 & $88,75 \%$ & Practical \\
\hline 3 & Increased Student Activity & 304 & $95 \%$ & Very Practical \\
\hline 4 & Available Time & 146 & $91,25 \%$ & Very Practical \\
\hline 5 & Evaluation & 143 & $89,37 \%$ & Practical \\
\hline \multicolumn{2}{|l|}{ Average practicality of Modules } & 91,31 & Very Practical \\
\hline
\end{tabular}


Based on Table 11, it can be seen the results of the responses of 20 students of Class IV A SDN 09 Airpura to the Indonesian learning module with the Contextual Teaching and Learning approach to the rhyming material of children with an average practicality of modules 91.31 and the category of Very Practical. Following are the results of the practicality test of Indonesian language learning modules with the Contextual Teaching and Learning approach in a nutshell by the students and the results of the practicality tes.

\section{DISCUSSION}

Based on the results of research conducted on a large scale at SDN 09 Airpura in the Indonesian learning process with the Contextual Teaching and Learning approach can be said to be very practical. According to Daryanto $(2013,13)$, modules need to be designed and developed by showing some elements that require them, including format and attractiveness. The learning process in rhyming material using modules makes students enthusiastic and happy to read all the pages in the module during the learning process. This is demonstrated by active students and enthusiasm during learning. Students are more serious in reading the modules they have.

Analysis of practicality test data results by Grade IV A students of SDN 09 Airpura shows that the Indonesian language learning module with the Contextual Teaching and Learning approach on child rhyming material that has been developed is very practical with a percentage of practicality 91.31. The figure is obtained from an average of five aspects of practicality of the modules assessed by students, namely aspects of student interest, the process of use, increased student creativity, time available, and evaluation.

From the aspect of student interest, the Indonesian language learning module with the Contextual Teaching and Learning approach to the child rhyme material that has been developed is declared very practical with a practical percentage of $92.18 \%$. This shows that modules that have been developed can increase students' interest in participating in learning. From the aspect of its use process, the Indonesian language learning module with the Contextual Teaching and Learning approach on child rhymes material that has been developed is declared practical with a practical percentage of $88.75 \%$. The results show that the modules that have been developed are easy to use by students independently with the guidance of the teacher. From the aspect of increasing student creativity, the Indonesian language learning module with the Contextual Teaching and Learning approach to the child rhyme material that has been developed is declared very practical with a percentage of practicality of $95 \%$. This shows that modules that have been developed can increase student learning creativity, and make learning more meaningful.

From the available time aspect, the Indonesian learning module with the Contextual Teaching and Learning approach to the child rhyme material that has been developed is declared very practical with a practicality percentage of $91.25 \%$. From the aspect of evaluating the Indonesian learning module with the Contextual Teaching and Learning approach to the child rhyme material that has been developed, it is declared practical with a practical percentage of $89.37 \%$. This shows that formative tests contained in the module can be a benchmark for students in understanding the material, and can help students better understand concepts. Daryanto (2013: 22) that evaluation is intended to find out and measure whether the implementation of learning with modules can be carried out in accordance with the design of its development. Therefore it can be concluded that the use of Indonesian learning modules with the Contextual Teaching and Learning (CTL) approach can help students in teaching and learning on a large scale at SDN 09 AirpuraPesisir Selatan. 


\section{CONCLUSION}

1. Indonesian learning modules with the Contextual Teaching and Learning approach in the material for children's rhymes for the fourth grade elementary school that have been developed are declared valid with an average percentage of validity 96.87 .

2. Indonesian learning modules with the Contextual Teaching and Learning approach on the material for children's rhymes for grade IV elementary schools that have been developed are declared very practical with an average percentage of practicality 100 by teachers and 91.31 by students.

\section{References}

[1] Hasan, MD Kamrul \& Akhand, Mhd. Moniruzzaman.: Approuches to Writing in EFL/ESL Context: Balancing Product and Process in Writing Class at Tertary Level. Journal of NELTA, Vol. 15 (1-2), pp. 77-79, 2010.

[2] Bowers, Lisa M \& Dostal, Hannah.: The Assesment of Writen Phrasal and Grammer of Deaf and Hard of Hearing Students with Varying Expressive Language Abilities. Education Research International. pp. 1-8, 2018.

[3] Kurniati, A.: Pengembangan Modul Matematika Berbasis Kontekstual Terintegrasi Ilmu Keislaman. Al-Khwarizmi: Jurnal Pendidikan Matematika dan Ilmu Pengetahuan Alam, 4(1), pp.43-58, 2016.

[4] Hanafy, M. S.: Konsep Belajar dan Pembelajaran. Lentera Pendidikan: Jurnal Ilmu Tarbiyah dan Keguruan, 17(1), 66-79, 2014.

[5] Fimansyah, D. Pengaruh Strategi Pembelajaran dan Minat Belajar Terhadap Hasil Belajar Matematika. JUDIKA (JURNAL PENDIDIKAN UNSIKA) 3, 2015.

[6] Biria, Reza \& Jafari, Sahar.: The Impact of Collabarative Writing on the Writing Fluency of Iranian Learners. Journal of Language Teching and Research, Vol. 4, 1, pp. 164-165, 2013.

[8] Gusmania, Y., \& Pamungkas, T.: Pengembangan Modul Geometri Analitik Bidang Berbasis Contextual Teaching Learning (CTL) untuk meningkatkan kompetensi mahasiswa Universitas Riau Kepulauan (UNRIKA). Jurnal Dimensi, Vol. 4, 2016.

[9] Suritanti \& Yaacop.: Exploring Teacher Strategies in Indonesia. Malaysian Journal of Learning and Instruction: Vol. 13, 2, 2016.

[10] Enoh, M.: Implementasi Contextual Teaching and Learning (CTL) dalam Kurikulum Berbasis Kompetensi Mata Pelajaran Geografi SMU/MA. Jurnal Ilmu Pendidikan Universitas Negeri Malang, pp. 11, 2016.

[11] Saputri, A. T. W., \& Mawardi, M.: Pengembangan Desain Pembelajaran Tematik Integratif Berbasis Pendekatan Contextual Teaching and Learning (CTL) Kelas 4 Sekolah Dasar. Jurnal Ilmiah Pendidikan Dasar, Vol. 4. pp. 104-114, 2018.

[12] Trianto.: Mendesain Dengan pendekatan Pembelajaran Inovatif-progresif. Jakarta: Kencana Prenada Media Group, 2009. 